\title{
Perencanaan Fondasi Tiang Bor Abutment Jembatan Kali Kendeng (Perbandingan Metode Meyerhof Dan Metode Reese \& Wright)
}

\section{Bored Pile Foundation Designing Of Kali Kendeng Bridge Abutment (Comparison Of Meyerhof Method And Reese \& Wright Method)}

\author{
Agus Susanto $^{1)}$, Renaningsih' ${ }^{2}$, and Riska Aditya Candrarini ${ }^{3)}$ \\ 1) Department of Civil Engineering, Universitas Muhammadiyah Surakarta, Jl. A. Yani Pabelan Kartasura \\ Tromol Pos I Surakarta Post Code 57102 \\ e-mail: as240@ums.ac.id \\ ${ }^{2)}$ Department of Civil Engineering, Universitas Muhammadiyah Surakarta, Jl. A. Yani Pabelan Kartasura \\ Tromol Pos I Surakarta Post Code 57102 \\ e-mail: ren186@ums.ac.id \\ ${ }^{3}$ Department of Civil Engineering, Universitas Muhammadiyah Surakarta, Jl. A. Yani Pabelan Kartasura \\ Tromol Pos I Surakarta Post Code 57102
}

\begin{abstract}
ABSTRAK
Fondasi merupakan struktur bawah yang berfungsi untuk meneruskan beban yang berasal dari struktur atas, baik beban dalam arah vertikal maupun horizontal ke tanah. Secara umum fondasi digolongkan menjadi dua golongan yaitu fondasi dangkal dan fondasi dalam. Jika suatu struktur dibangun di atas suatu lahan di mana lapisan tanah kerasnya terletak pada elevasi yang cukup dalam, maka tipe fondasi yang sesuai untuk struktur tersebut adalah fondasi dalam. Fondasi tiang bor (bored pile) merupakan salah satu jenis fondasi dalam yang dipasang ke dalam tanah dengan cara mengebor tanah terlebih dahulu, baru kemudian diisi tulangan dan dicor beton. Fondasi tiang ini biasanya dipakai pada tanah yang stabil sehingga memungkinkan untuk membentuk lubang yang stabil dengan mesin bor. Para ahli geoteknik telah merumuskan beberapa metode untuk perencanaan bored pile, diantaranya metode Meyerhof dan metode Reese \& Wright. Kedua metode tersebut menggunakan prinsip kombinasi end bearing dan friction pile. Pada perencanaan dengan metode Meyerhof menggunakan peramasamaan atau rumus, sedangkan pada metode Reese $\&$ Wright menggunakan gambar grafik. Penelitian ini bertujuan untuk mengetahui perbandingan kapasitas dukung ultimit tiang tunggal, kapasitas izin kelompok tiang dan jumlah fondasi bored pile yang dibutuhkan pada abutmen Jembatan Kali Kendeng Susukan, Semarang dengan metode Meyerhof dan metode Reese \& Wright. Data tanah yang digunakan untuk perencanaan bored pile adalah data nilai N-SPT lapisan tanah pada lokasi proyek jembatan. Sebelum melakukan analisis perhitungan kapasitas dukung, dilakukan perhitungan pembebanan, yaitu beban hidup, beban mati, dan beban kendaraan. Dari hasil perhitungan diperoleh bahwa beban aksial total yang harus ditahan oleh fondasi adalah sebesar 49881,266 kN. Kapasitas dukung ultimit tiang tunggal dengan metode Reese \& Wright diperoleh sebesar 5842,130 kN, dan dengan metode Meyerhof sebesar 4857,130 kN. Kapasitas izin kelompok tiang dengan metode Reese \& Wright sebesar 58421,300 kN dan Meyerhof sebesar 58285,560 kN, di mana keduanya sedikit lebih besar dari beban aksial yang harus ditahan, maka hasil hitungan dari kedua metode tersebut memenuhi untuk menahan beban. Dengan menggunakan SF 2,5 jumlah tiang bored pile yang dibutuhkan dengan metode Reese \& Wright diperoleh sebanyak 10 tiang, dan dengan metode Meyerhof diperoleh sebanyak 12 tiang.
\end{abstract}

Kata-kata kunci: Kapasitas dukung, metode Reese \& Wright, metode Meyerhof, nilai N-SPT, tiang bor

\section{ABSTRACT}

The foundation is the lower structure that functions to carry loads from the upper structure, both vertical and horizontal loads to the ground. In general, foundations are classified into two groups, namely shallow foundations and deep foundations. If a structure is built on land where the hard soil layer is located at a sufficiently deep elevation, then the suitable foundation type for the structure is deep foundation. Bored pile foundation is a type of deep foundation that is installed into the ground by drilling the ground first, then filling it with reinforcement and casting concrete. This pile foundation is usually used on stable soil so that it is possible to get a stable hole with a drilling machine. Geotechnical experts have formulated several methods for bored pile planning, including the Meyerhof method and the Reese \& Wright method. Both methods use the principle of a combination of end bearing and friction pile. In planning with the Meyerhof method uses equations or formulas, while the Reese \& Wright method uses graphic images. This study aims to determine the comparison of the ultimate single pile bearing capacity, pile group permit capacity and the number of bored pile foundations required on the abutments of the Kali Kendeng Susukan Bridge, Semarang using the Meyerhof method and the Reese \& Wright method. Soil data used for bored pile planning is the N-SPT value data for the soil layer at the bridge project site. Before analyzing the carrying capacity calculation, the load calculation is carried out, namely live load, dead load, and vehicle load. From the calculation results, it is found that the total axial load that must be held by the foundation is $49881.266 \mathrm{kN}$. The ultimate bearing capacity of a single pile using the Reese \& Wright method was obtained at $5842.130 \mathrm{kN}$, and by the Meyerhof method was $4857.130 \mathrm{kN}$. The allowed capacity of the pile group using the Reese \& Wright method is 58421,300 kN and Meyerhof's is 58285,560 kN, both of which are slightly larger than the axial load that must be held, so the calculation results of the two methods are satisfactory to withstand the load. By using SF 2.5 the number of bored piles required by the Reese \& Wright method was obtained as many as 10 poles, and by the Meyerhof method obtained as many as 12 poles.

Key words: Bearing capacity, Reese \& Wright method, Meyerhof method, N-SPT value, bored pile. 


\section{PENDAHULUAN}

Fondasi merupakan struktur bawah yang berfungsi untuk meneruskan beban yang berasal dari struktur atas, baik beban dalam arah vertikal maupun horizontal ke tanah. Secara umum fondasi digolongkan menjadi dua golongan yaitu fondasi dangkal dan fondasi dalam. Jika suatu struktur dibangun di atas suatu lahan di mana lapisan tanah kerasnya terletak pada elevasi yang cukup dalam, maka tipe fondasi yang sesuai untuk struktur tersebut adalah fondasi dalam.

Fondasi tiang bor (bored pile) merupakan salah satu jenis fondasi dalam yang dipasang ke dalam tanah dengan cara mengebor tanah terlebih dahulu, baru kemudian diisi tulangan dan dicor beton. Fondasi tiang ini biasanya dipakai pada tanah yang stabil sehingga memungkinkan untuk membentuk lubang yang stabil dengan mesin bor.

Proyek pembangunan jalan tol Semarang-Solo ruas Salatiga-Kartasura merupakan salah satu ruas jalan tol trans Jawa. Pada pembangunan jalan tol tersebut terdapat seksi E meliputi pekerjaan jembatan. Salah satu jembatan pada proyek tersebut adalah Jembatan Kali Kendeng dengan panjang $493 \mathrm{~m}$ dan lebar 25,2 $\mathrm{m}$.

Hasil pengujian tanah pada lokasi proyek Jembatan Kali Kendeng menunjukkan bahwa tanah pada lokasi proyek terdiri berupa lapisan non kohesif, dengan lapisan tanah keras berada pada kedalaman $12 \mathrm{~m}$. Memperhatikan alasan-alasan tertentu seperti karakteristik tanah, beban struktur atas, lingkungan sekitar proyek maka pada pembangunan Jembatan Kali Kendeng menggunakan fondasi tiang. Jenis fondasi tiang yang dipakai pada jembatan ini adalah fondasi tiang bor (bored pile).

Menurut Hardiyatmo (2015) salah satu keuntungan dalam pemakaian tiang bor dibandingkan dengan tiang pancang adalah pemasangannya tidak menimbulkan gangguan sura dan getaran yang membahayakan bangunan di sekitarnya. Fondasi tiang bor umumnya terdiri dari beberapa tiang dalam satu kelompok yang disatukan dengan pile cap. Para ahli geoteknik telah merumuskan beberapa metode untuk perencanaan pondasi tiang bor.

Jusi (2015) melekukan penelitian dengan judul Analisa Kuat Dukung Pondasi Bored Pile Berdasarkan Data Pengujian Lapangan (Cone dan N-Standard Penetration Test) dengan menggunakan beberapa metode antara lain metode O’Neil dan Reese, metode Meyerhoff dan metode Coyle \& Castello.

Yuliawan (2018) meneliti Analisis Daya Dukung dan Penurunan Pondasi Tiang Berdasarkan Pengujian SPT dan Cyclic Load Test. Nurochim (2017) melakukan penelitian dengan judul Analisis Daya Dukung Kelompok Tiang Bor pada Jembatan Moh Toha (di Proyek Penambahan Lajur Tol Kopo - Buah Batu) secara manual dengan metode Reese \& Wright dan menggunakan software Plaxis 3D.

Penelitian ini berupa perencanaan fondasi bored pile menggunakan metode Meyerhof dan metode Reese $\&$ Wright. Kedua metode tersebut menggunakan prinsip kombinasi end bearing dan friction pile. Pada perencanaan dengan metode Meyerhof menggunakan peramasamaan atau rumus sedangkan pada metode Reese \& Wright menggunakan gambar grafik.

Tujuan penelitian adalah untuk membandingan hasil hitungan kapasitas dukung ultimit tiang tunggal, kapasitas izin kelompok tiang dan jumlah fondasi bored pile yang dibutuhkan pada abutmen Jembatan Kenteng Susukan, Semarang dengan metode Meyerhof dan metode Reese \& Wright. Data tanah yang digunakan untuk perencanaan bored pile adalah data sekunder berupa data nilai N-SPT lapisan tanah pada lokasi proyek jembatan.

\section{LANDASAN TEORI}

\section{Kapasitas Dukung Fondasi Tiang}

Kapasitas dukung (bearing capacity) adalah kemampuan tanah di bawah dan sekitar fondasi untuk menahan beban yang bekerja dari struktur di atasnya. Kapasitas dukung bored pile diperoleh dari kuat dukung ujung (end bearing capacity), yang diperoleh dari tekanan ujung tiang dan kuat dukung geser atau selimut (friction bearing capacity) yang diperoleh dari kuat dukung gesek atau gaya adhesi antara bored pile dan tanah disekelilingnya. Bored pile berinteraksi dengan tanah untuk menghasilkan kuat dukung yang mampu memikul dan memberikan keamanan pada struktur atas (Jusi,2015).

Kapasitas dukung fondasi tiang dapat dihitung berdasarkan data tanah dari pengujian tanah di laboratorium atau pengujian tanah di lapangan. Pengujian tanah di laboratorium dilakukan untuk memperoleh nilai sifat fisis (index properties) dan sifat mekanis (engineering properties) tanah. Pengujian tanah di lapangan yang sering digunakan untuk menghitung kapasitas dukung tanah adalah pengujian Standard Penetration Test (SPT). Berdasarkan hasil pengujian SPT kapasitas dukung tiang bor dapat dihitung menggunakan metode Meyerhof dan metode Resse \& Wright.

\section{Metode Meyerhof}

Kapasitas dukung ultimit tiang bor $(\mathrm{Qu})$ menurut metode Meyerhof dapat dihitung menggunakan persamaan sebagai berikut, (Yuliawan, 2018)

$\mathrm{Qu}=\mathrm{Qb}+\mathrm{Qs}$

$\mathrm{Qu}=1 / 3.40 . \mathrm{Nb} b^{\prime} \cdot \mathrm{Ab}+0,2 \tilde{N}^{\prime} \cdot \mathrm{t} . \mathrm{k}$

Dengan

$\mathrm{Qu}=$ kapasitas dukung ultimit tiang

$\mathrm{Qb}=$ tahanan ujung ultimit tiang

Qs = tahanan gesek selimut tiang

$\mathrm{Ab}=$ luas penampang bored pile

$\mathrm{k}=$ keliling tiang

$\tilde{\mathrm{N}}$ '= nilai rata-rata $\mathrm{N}_{\mathrm{SPT}}$ terkoreksi sepanjang tiang

$\mathrm{Nb}^{\prime}=$ Nilai N-SPT terkoreksi ujung bawah tiang

$\mathrm{t}=$ tebal lapisan tanah

\section{Metode Reese \& Wright}

Kapasitas dukung ultimit tiang bor $(\mathrm{Qu})$ menurut metode Reese \& Wright dapat dihitung menggunakan persamaan sebagai berikut, (Nurachim, 2017)
$\mathrm{Qu}=\mathrm{Qp}+\mathrm{Qs}$
Dengan
$\mathrm{Qu}=$ kapasitas dukung ultimit tiang
$\mathrm{Qp}=$ tahanan ujung ultimit tiang 
Qs = tahanan gesek selimut tiang

$\mathrm{Q}_{\mathrm{p}}=\mathrm{qp} . \mathrm{A}$

Dengan

$\mathrm{Q}_{\mathrm{p}}=$ tahanan ujung ultimit tiang $(\mathrm{kN})$

$\mathrm{qp}=$ tahanan ujung per satuan luas $\left(\mathrm{kN} / \mathrm{m}^{2}\right)$

A = luas penampang tiang bor $\left(\mathrm{m}^{2}\right)$

Pada tanah non kohesif, Reese mengusulkan korelasi antara qp dengan N-SPT seperti terlihat pada Gambar 1.

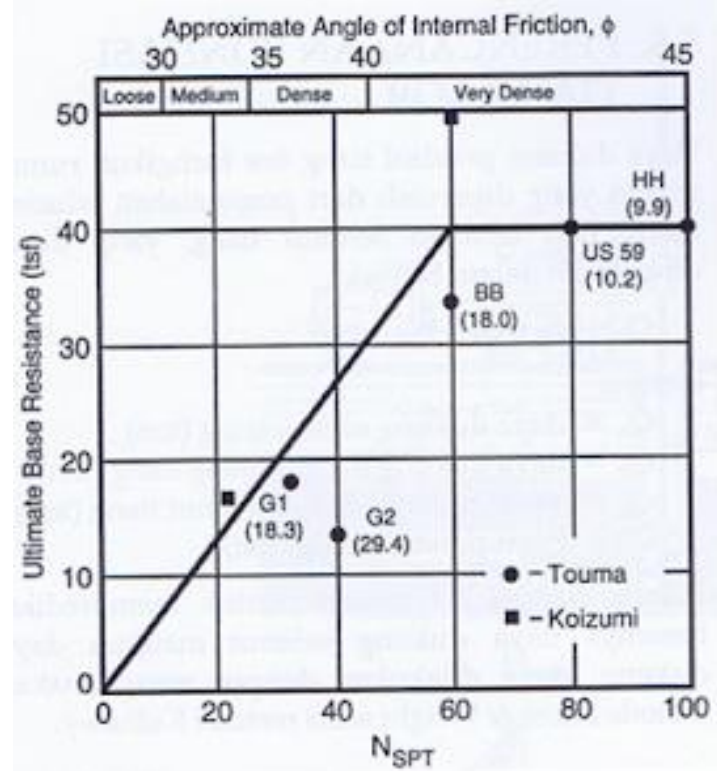

Gambar 1. Hubungan tahanan ujung ultimit dan N-SPT

$\mathrm{Q}_{\mathrm{s}}=\mathrm{f} . \mathrm{L} \cdot \mathrm{p}$

Dengan :

$\mathrm{Q}_{\mathrm{s}}=$ tahanan gesek ultimit tiang $(\mathrm{kN})$

$\mathrm{f}=$ gesekan selimut tiang $\left(\mathrm{kN} / \mathrm{m}^{2}\right)$

$\mathrm{L}=$ panjang tiang $(\mathrm{m})$

$\mathrm{p}=$ keliling penampang tiang $(\mathrm{m})$

Untuk tanah non kohesif, nilai f dapat diperoleh dengan korelasi langsung dengan nilai N-SPT seperti terlihat pada Gambar 2.

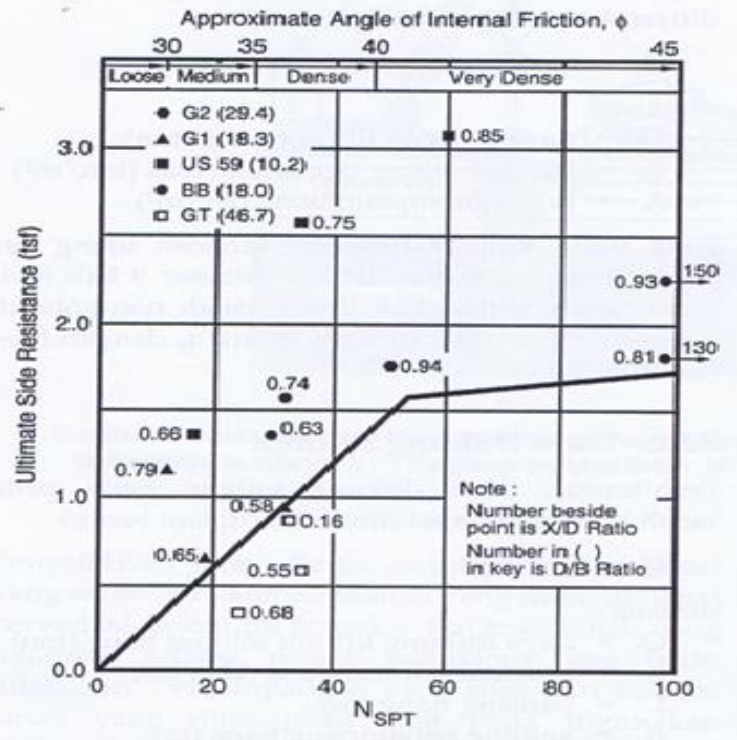

Gambar 2. Hubungan tahanan gesek selimut dan nilai NSPT

Kapasitas Dukung ijin (Qall)

Qall = Qu / SF

Dengan

Qall = kapasitas dukung ijin tiang

$\mathrm{Qu}=$ kapasitas dukung ultimit tiang

$\mathrm{SF}=$ faktor aman

Efisiensi Kelompok Tiang (Eg)

Persamaan pendekatan untuk mengestimasi efisiensi tiang yang disarankan oleh" Converse-Labarre Formula" sebagai berikut (Listyawan,2017),

$\mathrm{E}_{\mathrm{g}}=1-\theta \frac{(\mathrm{n}-1) \mathrm{m}+(\mathrm{m}-1) \mathrm{n}}{90 \mathrm{~mm}}$

Dengan :

$\mathrm{Eg}=$ Efisensi kelompok tiang

$\mathrm{m}=$ jumlah baris tiang

$\mathrm{n}=$ jumlah tiang dalam satu baris

$\Theta=\tan ^{-1}(\mathrm{~d} / \mathrm{s})$

$\mathrm{s}=$ jarak ke pusat tiang $(\mathrm{m})$

$\mathrm{d}=$ diameter tiang $(\mathrm{m})$

\section{TAHAPAN PENELITIAN}

Penelitian ini adalah berupa perencanaan fondasi tiang bor pada abutment Jembatan Kali Kendeng yang terdiri terdiri dari beberapa tahap yang dapat diuraikan sebagai berikut:

Tahap pertama berupa studi litearatur yang berkaitan dengan perencanaan tiang bor. Tahap ke dua berupa kegiatan pengumpulan data jembatan. Data yang diperoleh berupa data struktur jembatan dan hasil penyelidikan tanah yang didapatkan dari pihak Proyek Jalan Tol Salatiga-Solo seksi Jembatan. Data struktur jembatan meliputi struktur atas dan abutment jembatan. Hasil penyelidikan tanah yang digunakan berupa data nilai N-SPT dan bore $\log$.

Tahap ke tiga analisis pembebanan untuk menentukan besarnya beban yang harus ditahan oleh fondasi tiang bor. Tahap ke empat yaitu analisis kapasitas dukung ultimit tiang tunggal, menghitung jumlah tiang yang dibutuhkan dan kapasitas izin kelompok tiang bor..

Tahap ke lima membandingkan hasil hitungan perencanaan tiang bor menggunakan metode Meyerhof dan metode Reese \& Wright serta memengambil kesimpulan.

\section{HASIL DAN PEMBAHASAN}

Potongan memanjang dan melintang jembatan dapat dilihat pada Gambar 3 dan Gambar 4. 


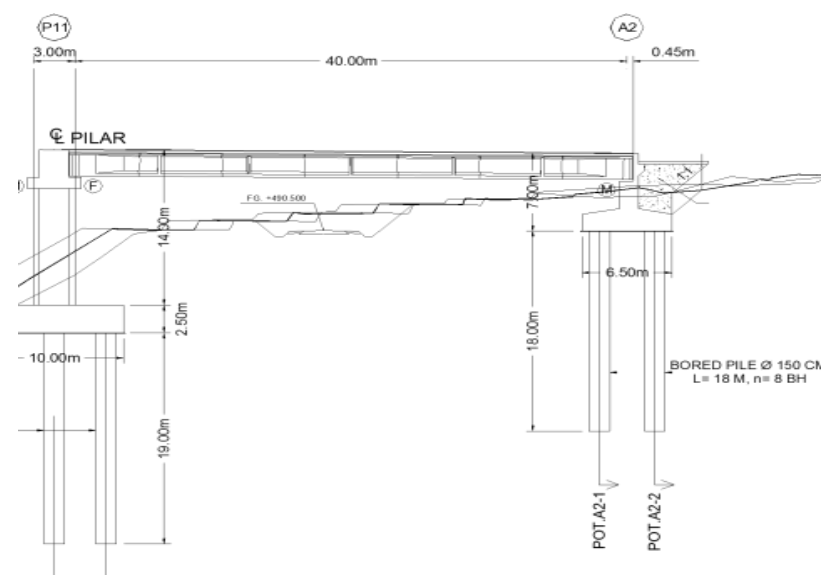

Gambar 3. Potongan memanjang jembatan $25.20 \mathrm{~m}$

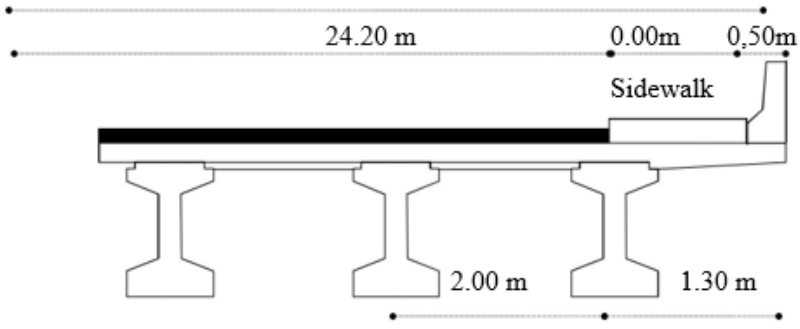

Gambar 4. Potongan melintang jembatan

Data teknis jembatan
1. Jenis jalan
: Jalan Tol
2. Jumlah lajur
: 2 lajur
3. Panjang jembat
: $493 \mathrm{~m}$
4. Lebar jembatan
: $25,20 \mathrm{~m}$
5. Panjang Gelagar
: $45,70 \mathrm{~m}$
6. Lebar lantai
: $11,70 \mathrm{~m}$
7. Tipe Gelagar
: PC I Girder
8. Jumlah gelagar
: 12 Buah
9. Tebal perkerasan $: 20 \mathrm{~cm}$

10. Konstruksi atas
a. Struktur atas
b. Plat lantai
: Beton prategang
: Lapis aspal beton

11. Konstruksi bawah
a. Abutment
: Beton Bertulang
b. Fondasi
: Bored Pile

Beban total yang harus ditahan oleh pondasi bored pile berasal dari penjumlahan beban-beban yang bekerja di atasnya yang terdiri dari beban mati, beban hidup, berat abutment dan berat tanah di atas telapak kaki abutment yaitu sebesar 49881,266 kN

Fondasi tiang bor direncanakan berdiameter $1,5 \mathrm{~m}$ yang ditanam sampai kedalaman $16 \mathrm{~m}$ yang juga berarti mencapai lapisan tanah keras. Data tanah pada abutment Jembatan Kali Kendeng diperoleh dari pengujian Standard Penetration Test (SPT) disajikan dalam Tabel 1.

Tabel 1. Data hasil pengujian SPT

\begin{tabular}{|c|c|}
\hline $\begin{array}{c}\text { Kedalaman } \\
\text { Tanah }(\mathrm{m})\end{array}$ & N-SPT \\
\hline 2 & 4 \\
\hline 4 & 10 \\
\hline 6 & 20 \\
\hline 8 & 15 \\
\hline
\end{tabular}

\begin{tabular}{|l|l|}
\hline 10 & 18 \\
\hline 12 & 60 \\
\hline 14 & 60 \\
\hline 16 & 60 \\
\hline
\end{tabular}

\section{Metode Reese \& Wright}

Tahanan ujung ultimit tiang $\left(\mathrm{Q}_{\mathrm{b}}\right)$

$\mathrm{Qb}=\mathrm{qp}$. A

Dengan

$\mathrm{qp}=$ tahanan ujung ultimit satuan

$\mathrm{A}=$ luas penampang tiang

Nilai qp diperoleh dari pembacaan pada Gambar 5. sesuai dengan data N-SPT di ujung tiang.

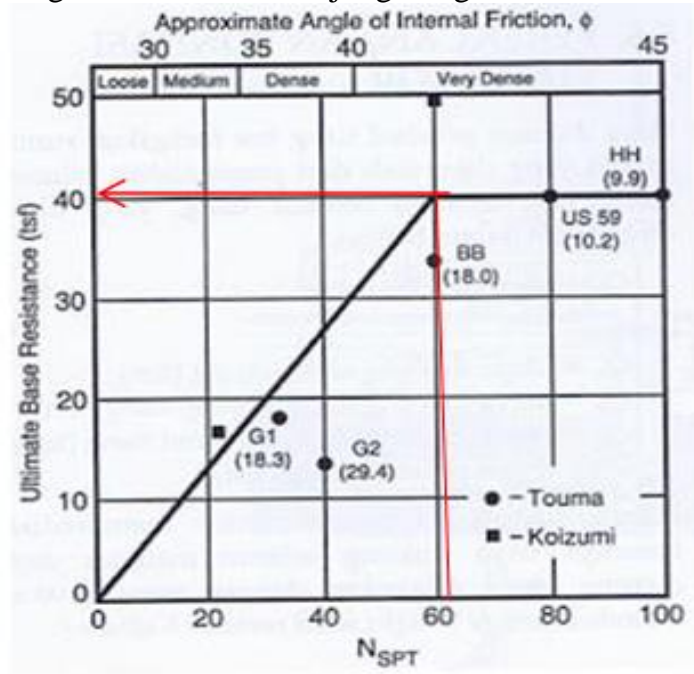

Gambar 5. Penentuan nilai tahanan ujung ultimit berdasarkan nilai N-SPT.

Nilai qp tahanan ujung ditentukan berdasarkan N-SPT pada ujung fondasi yaitu 60 maka dari Gambar 5 diperoleh $\mathrm{qp}=40 \mathrm{tsf}=4305,68 \mathrm{kN} / \mathrm{m}^{2}$

$$
\begin{aligned}
\mathrm{Q}_{\mathrm{b}} & =q p \cdot A \\
& =q p \cdot 0,25 \pi \mathrm{d}^{2} \\
& =4305,68 \cdot 0,25 \pi \cdot 1,5^{2} \\
& =7608,765 \mathrm{kN}
\end{aligned}
$$

Tahanan gesek ultimit tiang (Qs)

Tiang bor terletak pada tanah non kohesif, maka Qs dihitung dengan persamaan berikut :

$$
\mathrm{Q}_{s}=\sum_{l=1}^{n} f_{s} x l \times p
$$

fs = tahanan gesek selimut satuan

$1=$ tingggi lapisan tanah

$\mathrm{p}=$ keliling lingkaran

Nilai tahanan gesek selimut tiang (fs) pada masingmasing kedalaman diperoleh dari Gambar 6. 


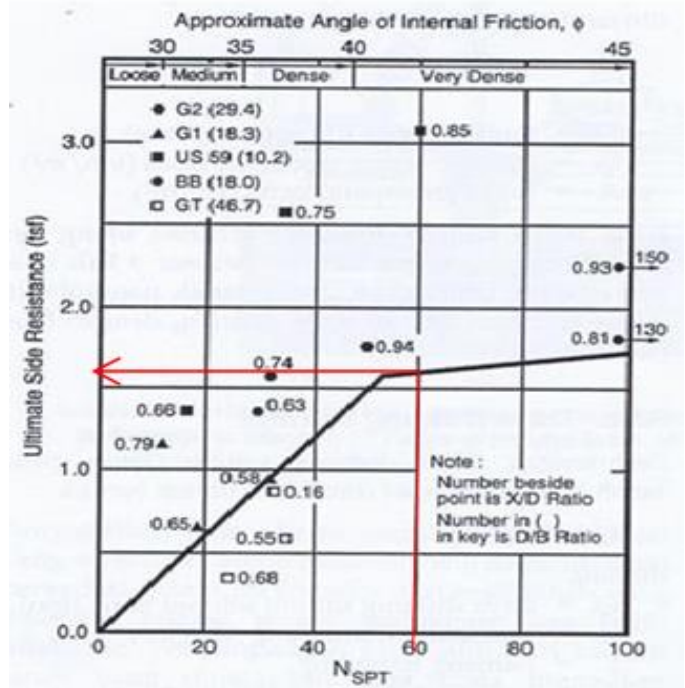

Gambar 6. Penentuan nilai tahanan gesek ultimit berdasarkan nilai N-SPT.

Berdasarkan Gambar 6, maka untuk nilai N-SPT $=60$ diperoleh nilai fs $=1,65 \mathrm{tsf}=177,610 \mathrm{kN} / \mathrm{m}^{2}$.

Keliling lingkaran (p)

$\mathrm{p}=\pi \cdot \mathrm{d}=\pi \cdot 1,5=4,712 \mathrm{~m}$

Dengan menggunakan membaca grafik hubungan N-SPT dan fs Gambar 6, maka didapat hasil fs pada tiap kedalaman tanah seperti terlihat pada Tabel 2.

Tabel 2. Nilai fs pada masing-masing kedalaman

\begin{tabular}{|c|c|c|c|c|}
\hline $\begin{array}{c}\text { Kedalaman } \\
\text { Tanah }(\mathrm{m})\end{array}$ & $\begin{array}{c}\mathrm{N}- \\
\text { SPT }\end{array}$ & $\begin{array}{c}\mathrm{fs} \\
(\mathrm{tsf})\end{array}$ & $\begin{array}{c}\mathrm{fs} \\
\left(\mathrm{kN} / \mathrm{m}^{2}\right)\end{array}$ & $\begin{array}{c}\text { Tinggi } \\
(\mathrm{m})\end{array}$ \\
\hline 2 & 4 & 0,1 & 10,764 & 2 \\
\hline 4 & 10 & 0,3 & 32,293 & 2 \\
\hline 6 & 20 & 0,6 & 64,586 & 2 \\
\hline 8 & 15 & 0,4 & 43,057 & 2 \\
\hline 10 & 18 & 0,55 & 59,203 & 2 \\
\hline 12 & 60 & 1,65 & 177,610 & 2 \\
\hline 14 & 60 & 1,65 & 177,610 & 2 \\
\hline 16 & 60 & 1,65 & 177,610 & 2 \\
\hline
\end{tabular}

Tiang bor terletak pada tanah yang berlapis, nilai Qs sebagai berikut :

$$
\mathrm{Q}_{s}=\sum_{l=1}^{n} f s x l \times p
$$

$$
\begin{aligned}
Q s= & (10,764 \times 2 \times 4,712)+(32,293 \times 2 \times 4,712)+ \\
& (64,586 \times 2 \times 4,712)+(43,057 \times 2 \times 4,712)+ \\
& (59,203 \times 2 \times 4,712)+(177,610 \times 2 \times 4,712)+ \\
& (177,610 \times 2 \times 4,712)+(177,610 \times 2 \times 4,712) \\
= & 101,442+304,327+608,654+405,770+557,933 \\
& +1673,800+1673,800+1673,800 \\
= & 6999,530 \mathrm{kN}
\end{aligned}
$$

Kapasitas dukung ultimit tiang $\left(\mathrm{Q}_{\mathrm{u}}\right)$

$\mathrm{Qu}=\mathrm{Qb}+\mathrm{Qs}$

$\mathrm{Qu}=7608,765+6999,530=14608,295 \mathrm{kN}$

Daya Dukung ijin (Qall)
Qall $=\mathrm{Qu} / \mathrm{SF}=14608,295 / 2,5=5843,318 \mathrm{kN}$

Jumlah tiang (n)

$\mathrm{n}=P / Q$ all $=49881,266 / 5843,318=8,536$ tiang,

maka dipakai $\mathrm{n}=10$ tiang

Susunan fondasi yang direncanakan seperti Gambar 7 sebagai berikut :

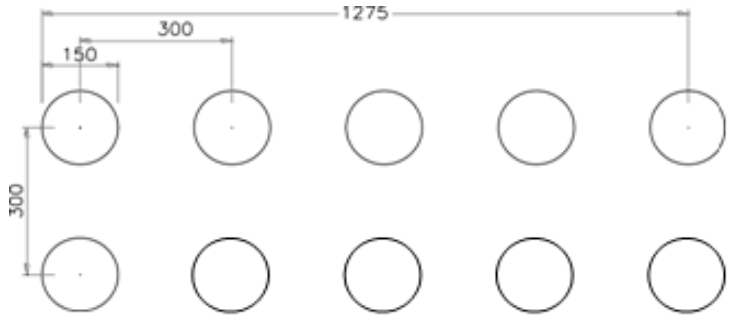

Gambar 7. Susunan Fondasi Taking Bor Metode Reese \& Wright

Efisiensi kelompok tiang

Hitungan efisiensi kelompok tiang ini menggunakan formula yang disarankan oleh Converse-Labarre formula (Hardiyatmo, 2015).

Diameter tiang $(\mathrm{d})=1,5 \mathrm{~m}$

Jarak antar tiang $(\mathrm{s})=3,0 \mathrm{~m}$

Jumlah tiang $\mathrm{n}=5$

$$
\mathrm{m}=2
$$

$\theta=\arctan (\mathrm{d} / \mathrm{s})=\arctan (1,5 / 3)=26,565$

Efisiensi kelompok tiang,

$$
\begin{aligned}
E_{g} & =1-\theta \frac{(n-1) m+(m-1) n}{90 m} \\
& =1-26,565 \cdot \frac{(5-1) 2+(2-1) 5}{90.25} \\
& =0,616
\end{aligned}
$$

Daya dukung kelompok ijin tiang

$Q_{g} \quad=E_{g} \cdot m \cdot n \cdot Q_{u}$

$$
\begin{aligned}
& =0,616 \times 2 \times 5 \times 14608,295 \\
& =89987,097 \mathrm{kN}>\mathrm{Pu}=49881,266 \mathrm{kN}(\mathrm{OK})
\end{aligned}
$$

Jadi dengan jumlah tiang sebanyak 2 x $5=10$ tiang, beban ijin yang dapat didukung kelompok tiang $Q_{g}=$ $89987,097 \mathrm{kN} \mathrm{kN}$ cukup untuk menahan beban yang bekerja.

\section{Metode Meyerhof}

Tahanan ujung ultimit tiang $(\mathrm{Qb})$

$\mathrm{Qb}=1 / 3.40 . \mathrm{N}^{\prime} . \mathrm{Ab}$

$$
\begin{aligned}
\mathrm{N}^{\prime} & =15+(\mathrm{N}-15) / 2=15+(60-15) / 2=37,5 \\
\mathrm{Ab} & =0,25 \pi \mathrm{d}^{2}=0,25 \pi 1,5^{2}=1,767 \mathrm{~m}^{2} \\
\mathrm{Qb} & =1 / 3 \cdot 40 . \mathrm{N}^{\prime} . \mathrm{Ab} \\
& =1 / 3 \cdot 40 \cdot 37,5 \cdot 1,767 \\
& =883,500 \text { ton } \\
& =8835 \mathrm{kN}
\end{aligned}
$$

Tahanan gesek ultimit tiang (Qs)

$\mathrm{Qs}=0,2 . \mathrm{N}^{\prime} \cdot \mathrm{k} . \mathrm{t}$ 
$\mathrm{k}=\pi \cdot \mathrm{D}=\pi \cdot 1,5=4,712 \mathrm{~m}$

Qs di hitung per lapisan tanah sesuai data N-SPT dan N', dapat dilihat pada Tabel 3.

Tabel 3. Nilai tahanan gesek tiang

\begin{tabular}{|c|c|c|c|c|}
\hline $\begin{array}{l}\text { Kedalama } \\
\text { n Tanah } \\
(\mathrm{m})\end{array}$ & $\begin{array}{c}\mathrm{N}- \\
\mathrm{SPT}\end{array}$ & $\mathrm{N}^{\prime}$ & $\begin{array}{c}\text { Keliling, } \\
\mathrm{k}(\mathrm{m})\end{array}$ & $\mathrm{Q}_{\mathrm{s}}(\mathrm{kN})$ \\
\hline 2 & 4 & 4 & 4,712 & 75,390 \\
\hline 4 & 10 & 10 & 4,712 & 188,480 \\
\hline 6 & 20 & 17,5 & 4,712 & 329,840 \\
\hline 8 & 15 & 15 & 4,712 & 282,720 \\
\hline 10 & 18 & 16,5 & 4,712 & 310,990 \\
\hline 12 & 60 & 37,5 & 4,712 & 706,800 \\
\hline 14 & 60 & 37,5 & 4,712 & 706,800 \\
\hline 16 & 60 & 37,5 & 4,712 & 706,800 \\
\hline & & & $\Sigma \mathrm{Q}_{\mathrm{s}}$ & 3307,820 \\
\hline
\end{tabular}

Daya Dukung Ultimit Tiang $(\mathrm{Qu})$

$\mathrm{Qu}=\mathrm{Q}+\mathrm{Qs}$

$=8835+3307,820$

$=12142,820 \mathrm{kN}$

Daya Dukung Ijin (Qall)

$\mathrm{Q}_{\text {all }}=\mathrm{Qu} / \mathrm{SF}=12142,820 / 2,5=4857,130 \mathrm{kN}$

Jumlah tiang (n)

$\mathrm{n}=P / \mathrm{Q}_{\text {all }}=49881,266 / 4857,130==10,269$ tiang

maka dipakai $\mathrm{n}=12$ tiang.

Susunan fondasi yang direncanakan seperti Gambar 8 sebagai berikut :

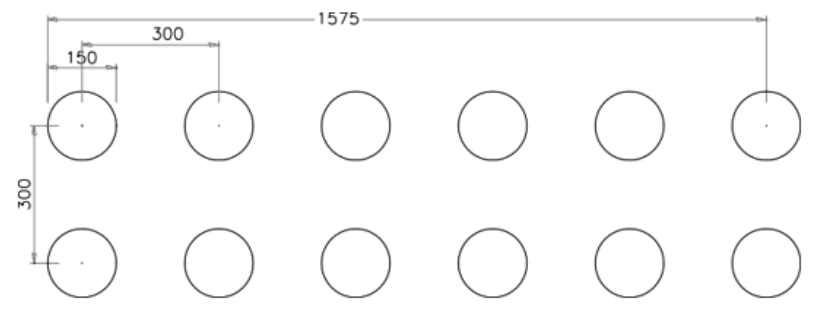

Gambar 8. Susunan Fondasi Tiang Bor Metode Meyerhof

Efisiensi kelompok tiang

Diameter tiang $(\mathrm{d})=1,5 \mathrm{~m}$

Jarak antar tiang $(\mathrm{s})=3,0 \mathrm{~m}$

Jumlah tiang $\mathrm{n}=6$

$\mathrm{m}=2$

$\theta=\arctan (\mathrm{d} / \mathrm{s})=\arctan (1,5 / 3)=26,565$

Efisiensi kelompok tiang,

$$
\begin{aligned}
E_{g} & =1-\theta \frac{(n-1) m+(m-1) n}{90 m n} \\
& =0,606
\end{aligned}
$$

Daya dukung kelompok ijin tiang

$Q_{g} \quad=E_{g} \cdot m \cdot n \cdot Q_{u}$

$=0,606 \times 2 \times 6 \times 12142,820$

$$
=88302,857 \mathrm{kN}>\mathrm{Pu}=49881,266 \mathrm{kN}(\mathrm{OK})
$$

Jadi dengan jumlah tiang sebanyak $2 \times 6=12$ tiang, beban yang dapat didukung kelompok tiang $Q_{g}=$ $88302,857 \mathrm{kN} \mathrm{kN} \mathrm{kN}$ cukup untuk menahan beban.

Perbandingan hasil hitungan kapasitas dukung ultimit dan kapasitas izin kelompok, serta jumlah tiang metode Reese \& Wright dan Meyerhof dapat dilihat pada Tabel 4.

Tabel 4. Perbandingan hasil hitungan metode Reese \& Wright dan metode Meyerhof

\begin{tabular}{|c|c|c|c|c|}
\hline Metode & $\begin{array}{c}\mathrm{Q}_{\mathrm{u}} \\
(\mathrm{kN})\end{array}$ & $\begin{array}{c}\mathrm{Q}_{\text {all }} \\
(\mathrm{kN})\end{array}$ & $\begin{array}{c}\mathrm{Q}_{\mathrm{g}} \\
(\mathrm{kN})\end{array}$ & $\mathrm{n}$ \\
\hline $\begin{array}{c}\text { Reese } \\
\& \\
\text { Wright }\end{array}$ & 14605 & 5842 & 58421 & 10 \\
\hline $\begin{array}{c}\text { Mayer- } \\
\text { hoff }\end{array}$ & 12143 & 4857 & 58285 & 12 \\
\hline
\end{tabular}

Tabel 7. menunjukkan bahwa hitungan metode Reese \& Wright menghasilkan jumlah tiang yang dibutuhkan untuk menahan beban lebih sedikit dibandingkan metode Meyerhof. Namun demikian ketelitian metode ini kurang baik karena pada proses hitungannya perlu membaca grafik, sehingga hasilnya dipengaruhi oleh ketajaman mata pembaca. Selain itu suatu perenacanaan yang baik perlu mengedepankan prisip kehati-hatian sehingga pada kasus ini direkomendasikan memilih jumlah tiang yang lebih banyak yaitu dari hasil hitungan menggunakan metode Meyerhof.

\section{KESIMPULAN}

1. Kapasitas dukung ultimit fondasi bored pile tunggal dengan diameter $1,5 \mathrm{~m}$ dengan panjang $16 \mathrm{~m}$ dihitung dengan metode Reese \& Wright diperoleh sebesar 5842,130 kN/tiang, dan metode Meyerhof sebesar 4857,130 kN/tiang,

2. Kapasitas izin kelompok tiang fondasi bored pile metode Reese \& Wright sebesar 58421,300 kN dan Meyerhof sebesar 58285,560 kN, dengan beban total (P) sebesar 49881,266 kN yang berarti kedua memenuhi untuk menopang beban total $(\mathrm{P})$ tersebut,

3. Jumlah tiang bor yang dibutuhkan untuk menahan beban total dengan SF 2,5 dengan metode Reese \& Wright adalah sebanyak 10 buah tiang dan dengan metode Meyerhof adalah sebanyak 12 buah tiang.

4. Perenacanaan fondasi yang baik perlu mengedepankan prisip kehati-hatian sehingga pada kasus ini direkomendasikan memilih jumlah tiang yang lebih banyak yaitu dari hasil hitungan menggunakan metode Meyerhof

\section{DAFTAR PUSTAKA}

Hardiyatmo, H. C., 2015. Analisis dan Perancangan Fondasi II. Gadjah Mada University Press, Edisi Ke-3 Mei 2015, pp 77. Jusi, U., 2015. Analisa Kuat Dukung Pondasi Bored Pile Berdasarkan Data Pengujian Lapangan (Cone dan N- 
Standard Penetration Test). In : Jurnal Teknik Sipil Siklus Volume 1 No. 2 Oktober 2015, pp 50.

Listyawan, A. B., 2017. Mekanika Tanah dan Rekayasa Pondasi. Muhammadiyah University Press, Edisi 2017, pp 260.

Nurachim, L., 2017. Analisis Daya Dukung Kelompok Tiang Bor pada Jembatan Moh Toha (di Proyek Penambahan Lajur Tol Kopo-Buah Batu). In: Jurnal Online Reka Racana Jurusan Teknik Sipil Itenas No 4 Volume 3 Desember 2017, pp 1-11.

Yuliawan, E., 2018. Analisis Daya Dukung dan Penurunan Pondasi Tiang Berdasarkan Pengujian SPT dan Cyclic Load Test. In: Jurnal Konstruksia Volume 9 No 2 Juli 2018, pp 113. 